\author{
BARTŁOMIEJ GLINA ${ }^{1 *}$, ADAM BOGACZ ${ }^{2}$, PRZEMYSŁAW WOŹNICZKA ${ }^{2}$ \\ ${ }^{1}$ Poznań University of Life Science, Department of Soil Science and Land Protection \\ Szydlowska Str. 50, 60-656 Poznań, Poland \\ ${ }^{2}$ Wrockaw University of Environmental and Life Sciences, Institute of Soil Science and Environmental Protection \\ Grunwaldzka Str. 53, 50-357 Wrocław, Poland
}

\title{
Nitrogen mineralization in forestry-drained peatland soils in the Stolowe Mountains National Park (Central Sudetes Mts)
}

\begin{abstract}
The aim of this work was to determine the intensity of nitrogen mineralization in forestry drained ombrotrophic peatland soils in the Stołowe Mountains National Park, SW Poland. Additionally discussion about the shallow organic soils classification according to Polish Soil Classification (2011) is presented. For the study three research transects were established on forestry drained ombrotrophic peatlands in the Stołowe Mountains. Each of the transect consisted of four (site A and B) or five (site C) sampling plots. Sampling was conducted in the year 2012. The soil samples for the basic soil properties analysis were sampled in April, whereas undisturbed soil samples were collected in stainless steel rings $\left(100 \mathrm{~cm}^{3}\right)$ every $10 \mathrm{~cm}$ in April (spring), July (summer) and October (autumn) to show the seasonal dynamics of nitrogen mineralization. Statistical analysis showed that the content of $\mathrm{N}-\mathrm{NH}_{4}$ was mainly determined by actual soil moisture and precipitation rate, whereas the content of $\mathrm{N}-\mathrm{NO}_{3}$ was positively correlated with air temperature. Among investigated peatlands the highest concentrations of mineral nitrogen forms was observed in the Długie Mokradło bog, situated on the Skalniak Plateau-summit. Additionally, the results obtained showed that implementation of new subtype: shallow fibric peat soils (in Polish: gleby torfowe fibrowe płytkie) within the type of peat soils (in polish: gleby torfowe) should be considered during developing of the next update of Polish Soil Classification.
\end{abstract}

Keywords: mineral nitrogen, forestry, drainage, peat bogs, Sudetes Mts

\section{INTRODUCTION}

The pressure on peatland ecosystems is likely to be mediated through changes in hydrology, direct and indirect effects of climate change, as well as land-use change (Ferrati et al. 2005). In most cases this phenomenon is the effect of strong human impact such as drainage for forestry or agricultural use of peatlands (Limpens et al. 2008). The human impact increased peatlands vulnerability to climate change, what exacerbated the negative effects of drainage (Charman et al. 2008). This process also concerned mountain peatlands, drained mainly for forestry use (Yallop and Clutterbuck 2009). In the Stołowe Mountains (Central Sudetes, SW Poland) large peatland complexes were drained to obtained a new area for spruce monoculture at the turn of $19^{\text {th }}$ and $20^{\text {th }}$ centuries (Stark 1936, Jędryszczak and Miścicki 2001). The decrease of the water table increases aerobic conditions in the surface layers of peatland soils, what promotes mursh-forming process connected with mineralization of organic matter (Markiewicz et al. 2015), including nitrogen compounds (Maljanen et al. 2007). Moreover, this phenomenon is reinforced by the increase of evapotranspiration from the afforested peatland surface
(Gillooly et al. 2001). The intensity of mineralization process mainly depends on actual soil moisture (Weedon et al. 2012), type of organic matter (Schimel and Bennett, 2004), type of peatland management (Tripathi and Sighn 2009), soil fauna (Lappalainen et al. 1999 Weedon et al. 2012), and air temperature (Ehrenfeld and Shen Yu 2012). Furthermore, mineral nitrogen forms $\left(\mathrm{N}-\mathrm{NH}_{4}\right.$ and $\left.\mathrm{N}-\mathrm{NO}_{3}\right)$ display seasonal variations, what indicates the necessity of measurement in different time period and weather conditions (Basiliko et al. 2005, Gao et al. 2009). In Poland, the problem of nitrogen mineralization in the peat soils was particularly discussed with respect to degraded lowland minerotrophic peatlands (e.g. Turbiak and Miatkowski 2006, Pawluczuk and Szymczyk 2008). However, this problem should be also considered in order to forestry drained peatland ecosystems in mountain areas, what will be described in the presented work.

The aim of this work was to determine the intensity of nitrogen mineralization in forestry drained peatland soils in the Stołowe Mountains National Park (SMNP), in the year 2012. Additionally, authors will discuss problems of shallow organic soils classification according to Polish Soil Classification (PSC 2011) which revealed during the preparation of this work. 


\section{MATERIALS AND METHODS}

The study was conducted in the Stołowe Mountains National Park situated in the south-west of Poland (Figure 1). The mean annual air temperature in the sampling year 2012 was $6.7^{\circ} \mathrm{C}$, in the warmest month (July) $17.0^{\circ} \mathrm{C}$, whereas in the coldest (February) $7.5^{\circ} \mathrm{C}$. The annual sum of precipitation in 2012 was $786 \mathrm{~mm}$ with the maximum in July $(169 \mathrm{~mm})$ and minimum in March - $14 \mathrm{~mm}$ (Table 1). Growing period in SMNP begins in the second or in the third decade of April and lasts 190 days (Gałka et al. 2014).

For the study, three research transects were established on forestry drained ombrotrophic peatlands

TABLE 1. Temperature and precipitation during the growing season in $2012 *$ (SMNP)

\begin{tabular}{lcccccccc}
\hline Months & III & IV & V & VI & VII & VIII & IX & X \\
\hline $\begin{array}{l}\text { Temperature } \\
\left({ }^{\circ} \mathrm{C}\right)\end{array}$ & 3.1 & 6.6 & 13.0 & 15.5 & 17.0 & 16.0 & 11.3 & 6.0 \\
\hline $\begin{array}{l}\text { Precipitation } \\
(\mathrm{mm})\end{array}$ & 14 & 43 & 55 & 59 & 169 & 78 & 58 & 61 \\
\hline
\end{tabular}

* data from the meteorological station in Kudowa Zdrój. into the stainless steel rings $\left(100 \mathrm{~cm}^{3}\right)$ in April (spring), July (summer), and October (autumn), every $10 \mathrm{~cm}$ of profile $(0-10 \mathrm{~cm}, 10-20 \mathrm{~cm}, 20-30 \mathrm{~cm}$ etc.). The amount of collected samples was conditioned by thickness of each soil profile. Additionally, in April soil samples were sampled from genetic horizons for the basic soil properties analysis (Table 2). For groundwater table control along the research transects thirteen piezometers were installed. Each soil sample was divided into two subsamples prior to laboratory analysis. In fresh material the degree of peat decomposition was determined following the procedure proposed by Lynn et al. (1974). The following properties were determined in the dry soil material: ash content after placing dried samples for $5 \mathrm{~h}$ in a muffle furnace at $550^{\circ} \mathrm{C}$ (Bojko and Kabała 2014), pH in distilled water (soil to water $\mathrm{w} / \mathrm{v}$ ratio $1: 2.5)$ potentiometrically, total organic carbon (TOC) by catalytic dry combustion at $600^{\circ} \mathrm{C}$ in Ströhlein CS-mat 5500 analyzer, and total nitrogen (TN) by Kjeldahl method using Büchii analyzer. The concentration of nitrate $\left(\mathrm{N}-\mathrm{NO}_{3}\right)$ and ammonium $\left(\mathrm{N}-\mathrm{NH}_{4}\right)$ forms were measured spectrometrically in $1 \% \mathrm{~K}_{2} \mathrm{SO}_{4}$ extracts with Nessler's reagent (for $\mathrm{NH}_{4}$ ) and phenol disulfonic acid (for $\mathrm{NO}_{3}$ ) after 14 days
(Figure 1). Each of the transect consisted of four (sites A and B) or five (site C) soil profiles (Figure 1, Table 1). Transect A was established along the ransitional bog situated on the Rogowa Kopa plateau in the southern part of SMNP. This peatland is characterized by mixed ombrogenous-soligenous type of water supply (Glina 2014). Research transects B and C were respectively established on Niknąca Łąka and Długie Mokradło bogs. Both study sites are typical omborogenous peatlands, developed over the sandstone bedrock (Bogacz et al. 2012, Glina 2014). The study site $\mathrm{C}$ is the most densely cut by drainage ditches among all of the described area. All of the peatlands are covered by forest communities with domination of spruces, pines and birches (Glina 2014). The field works and soil sampling campaigns were carried out during the growing season in the year 2012. To show the seasonal dynamics of nitrogen mineralization undisturbed soil samples were collected in triplicate

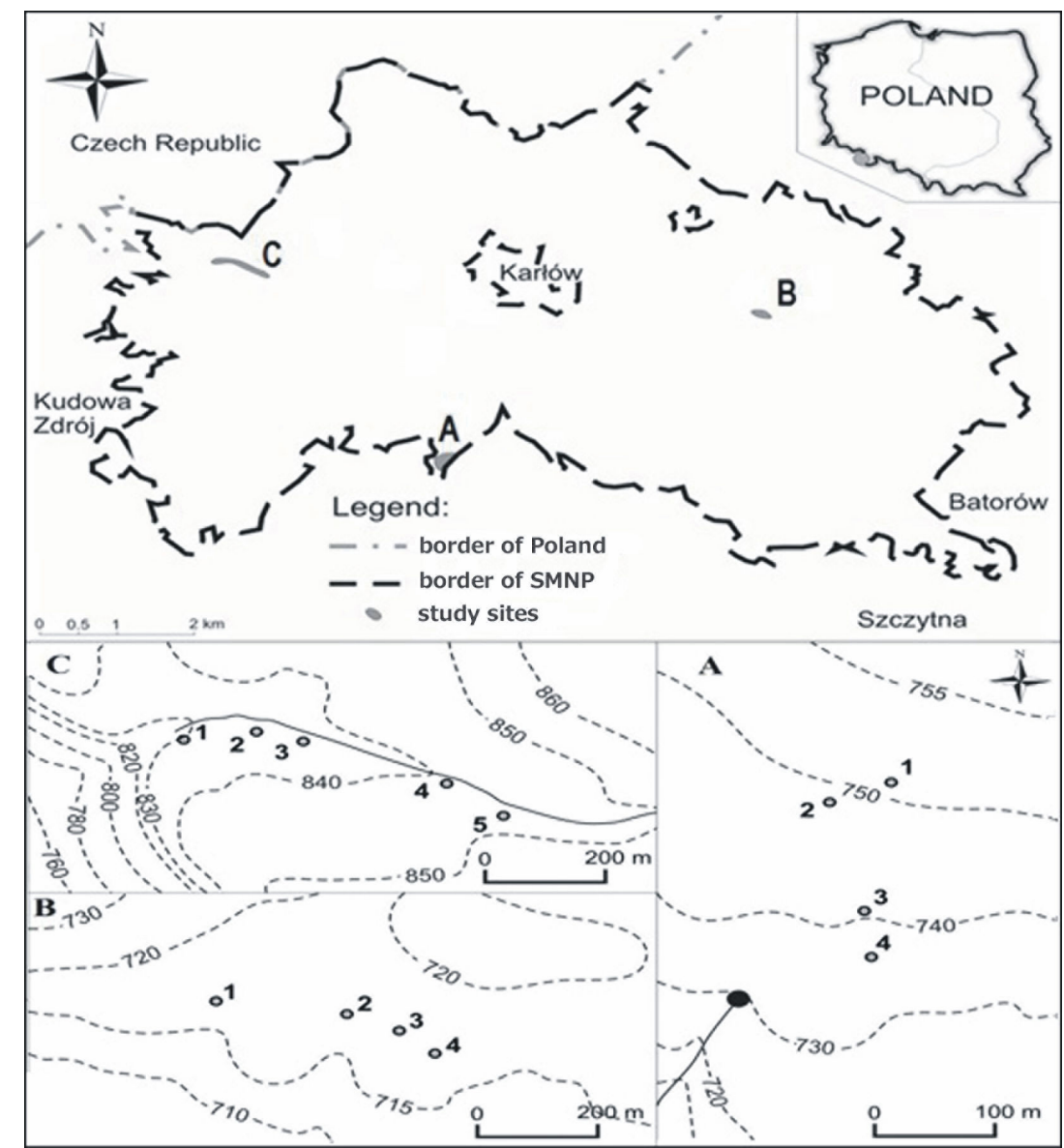

FIGURE 1. Location of the study sites and transects sketch 
TABLE 2. Soil profile location and classification

\begin{tabular}{|c|c|c|c|c|c|}
\hline \multirow{2}{*}{$\begin{array}{l}\text { Study } \\
\text { site }\end{array}$} & \multirow{2}{*}{$\begin{array}{l}\text { Profile } \\
\text { No. }\end{array}$} & \multirow{2}{*}{$\begin{array}{l}\text { Depth } \\
(\mathrm{cm})\end{array}$} & \multirow{2}{*}{$\begin{array}{l}\text { Coordinates } \\
\text { WGS } 84 \text { (N/E) }\end{array}$} & \multicolumn{2}{|l|}{ Soil classification } \\
\hline & & & & PSC 2011 & FAO-WRB 2015 \\
\hline \multirow[t]{4}{*}{ A } & 1 & 36 & $\begin{array}{l}50^{\circ} 27^{\prime} 00.0^{\prime \prime \prime} \\
16^{\circ} 20^{\prime} 12.7^{\prime \prime} \\
\end{array}$ & gleba torfowo-glejowa & $\begin{array}{l}\text { DystricHistic Gleysol } \\
\text { (Drainic) }\end{array}$ \\
\hline & 2 & 31 & $\begin{array}{l}50^{\circ} 26^{\prime} 59.2^{\prime \prime \prime} \\
16^{\circ} 20^{\prime} 10.1^{\prime \prime} \\
\end{array}$ & gleba torfowo-glejowa & $\begin{array}{l}\text { DystricHistic Gleysol } \\
\text { (Drainic) }\end{array}$ \\
\hline & 3 & 32 & $\begin{array}{l}50^{\circ} 26^{\prime} 55.2^{\prime \prime \prime} \\
16^{\circ} 20^{\prime} 11.8^{\prime \prime}\end{array}$ & gleba torfowo-glejowa & $\begin{array}{l}\text { DystricHistic Gleysol } \\
\text { (Drainic) }\end{array}$ \\
\hline & 4 & 31 & $\begin{array}{l}50^{\circ} 26^{\prime} 53.5^{\prime \prime \prime} \\
16^{\circ} 20^{\prime} 12.2^{\prime \prime} \\
\end{array}$ & gleba torfowo-glejowa & $\begin{array}{l}\text { DystricHistic Gleysol } \\
\text { (Drainic) }\end{array}$ \\
\hline \multirow[t]{4}{*}{ B } & 1 & 43 & $\begin{array}{l}50^{\circ} 27^{\prime} 58.5^{\prime \prime \prime} \\
16^{\circ} 23^{\prime} 26.7^{\prime \prime} \\
\end{array}$ & $\begin{array}{l}\text { gleba torfowa saprowa } \\
\text { płytka }\end{array}$ & $\begin{array}{l}\text { Dystric Ombric Drainic } \\
\text { Sapric Histosol }\end{array}$ \\
\hline & 2 & 54 & $\begin{array}{l}50^{\circ} 27^{\prime} 57.8^{\prime \prime \prime} \\
16^{\circ} 23^{\prime} 37.7^{\prime \prime}\end{array}$ & $\begin{array}{l}\text { gleba torfowa fibrowa } \\
\text { typowa }\end{array}$ & $\begin{array}{l}\text { Dystric Ombric Drainic } \\
\text { Fibric Histosol }\end{array}$ \\
\hline & 3 & 70 & $\begin{array}{l}50^{\circ} 27^{\prime} 58.5^{\prime \prime} / \\
16^{\circ} 23^{\prime} 26.7^{\prime \prime} \\
\end{array}$ & $\begin{array}{l}\text { gleba torfowa } \\
\text { hemowo-fibrowa }\end{array}$ & $\begin{array}{l}\text { Dystric Ombric Drainic } \\
\text { Hemic Fibric Histosol }\end{array}$ \\
\hline & 4 & 45 & $\begin{array}{l}50^{\circ} 27^{\prime} 55.1^{\prime \prime \prime} \\
16^{\circ} 23^{\prime} 45.2^{\prime \prime} \\
\end{array}$ & $\begin{array}{l}\text { gleba torfowa fibrowa } \\
\text { typowa }\end{array}$ & $\begin{array}{l}\text { Dystric Ombric Drainic } \\
\text { Fibric Histosol }\end{array}$ \\
\hline \multirow[t]{5}{*}{$\mathrm{C}$} & 1 & 40 & $\begin{array}{l}50^{\circ} 28^{\prime} 27.8^{\prime \prime \prime} \\
16^{\circ} 17^{\prime} 21.3^{\prime \prime}\end{array}$ & $\begin{array}{l}\text { gleba torfowa saprowa } \\
\text { płytka }\end{array}$ & $\begin{array}{l}\text { Dystric Drainic Sapric } \\
\text { Histosol }\end{array}$ \\
\hline & 2 & 45 & $\begin{array}{l}50^{\circ} 28^{\prime} 28.5^{\prime \prime} / \\
16^{\circ} 17^{\prime} 27.5^{\prime \prime}\end{array}$ & $\begin{array}{l}\text { gleba torfowa } \\
\text { hemowo-fibrowa }\end{array}$ & $\begin{array}{l}\text { Dystric Ombric Drainic } \\
\text { Hemic Fibric Histosol }\end{array}$ \\
\hline & 3 & 53 & $\begin{array}{l}50^{\circ} 28^{\prime} 31.5^{\prime \prime \prime} \\
16^{\circ} 17^{\prime} 27.9^{\prime \prime} \\
\end{array}$ & $\begin{array}{l}\text { gleba torfowa fibrowo- } \\
\text { saprowa }\end{array}$ & $\begin{array}{l}\text { Dystric Ombric Drainic } \\
\text { Sapric Fibric Histosol }\end{array}$ \\
\hline & 4 & 64 & $\begin{array}{l}50^{\circ} 28^{\prime} 25.1^{\prime \prime \prime} \\
16^{\circ} 17^{\prime} 43.8^{\prime \prime} \\
\end{array}$ & $\begin{array}{l}\text { gleba torfowa fibrowa } \\
\text { typowa }\end{array}$ & $\begin{array}{l}\text { Dystric Ombric Drainic } \\
\text { Hemic Fibric Histosol }\end{array}$ \\
\hline & 5 & 43 & $\begin{array}{l}50^{\circ} 28^{\prime} 22.8^{\prime \prime} / \\
16^{\circ} 17^{\prime} 48.8^{\prime \prime}\end{array}$ & $\begin{array}{l}\text { gleba torfowa fibrowa } \\
\text { typowa }\end{array}$ & $\begin{array}{l}\text { Dystric Drainic Fibric } \\
\text { Histosol }\end{array}$ \\
\hline
\end{tabular}

incubations at $28^{\circ} \mathrm{C}$ (Gotkiewicz 1974) in climatic chambers (THe AG-1440), with daily controls of the soil moisture. All soil samples were analyzed in triplicate. Obtained results of nitrogen mineralization were statistically collated with actual soil moisture, groundwater level, monthly mean air temperature and monthly sum of precipitation. Statistical analysis was done using Statistica software system (StatSoft Inc. Tulsa, OK).

\section{RESULTS AND DISCUSSION}

\section{Classification of studied soils}

Based on the morphological features and physicochemical properties, investigated soils were classified according to PSC (2011) and FAO-WRB (IUSS Working Group WRB 2015). According to WRB, studied soils belong to two reference groups: Gleysols (Profiles 1-4) and Histosols (Profiles 5-13) with addition of various principal and supplementary qualifiers (see Table 2). Criteria of PSC (2011) allowed to classify soil profiles along the transect A (profiles 1-4) as peat gleysols (in Polish: gleby torfowo-glejowe), whereas shallow organic soils from study sites $B$ and $C$ represented various types of peat soils (in Polish: gleby torfowe). In the author's opinion, shallow organic soils have been omitted in the actual PSC (2011). It is clearly stated that organic soils classification has to be done based on the dominant soil material in the center layer „piętro środkowe" (40-100 cm), while in some cases of shallow peat soils the organic layer thickness slightly exceed $40 \mathrm{~cm}$. In such situations, the most sensible approach would be to determine the subtype of the shallow organic soils based on the dominant type of peat material (sapric, hemic, fibric) in the profile. Present version of PSC (2011) defined only the minimum organic layer thickness $(\geq 40 \mathrm{~cm})$ for shallow organic soils. In the author's opinion the depth limit should be also clearly define (the author's proposal is $80 \mathrm{~cm}$ ). This proffers should be considered during developing of the next Classification of Polish Soils update. Additionally the new subtype within the type of peat soils (in Polish: gleby torfowe) should be implement to the classification: shallow fibric peat soils (in Polish: gleby torfowe fibrowe płytkie). This classification unit could include shallow organic soils (organic material thickness $\geq 40 \mathrm{~cm}$ and $\leq 80 \mathrm{~cm}$ ) mainly consists of fibric peat material and lying directly on mineral bedrock. Above mentioned proposals have been presented based on the results obtained in this study. However, heterogeneous shal- 
low organic soils consisting of various peat materials are present also in other parts of the Stołowe Mountains (Bogacz and Roszkowicz 2010, Bogacz and Rutkowska 2010, Glina et al. 2013) other ranges of Sudetes Mountains (Bogacz 2005, Bogacz and Ochej 2008, Glina and Bogacz 2013, Kabała (ed.) 2015), as well as in Polish part of Carpathian Mountains (Lajczak 2013).

\section{Seasonal dynamics of nitrogen mineralization}

The $\mathrm{C} / \mathrm{N}$ ratio in the investigated soils was mainly above the 20 (Table 3 ). The $\mathrm{C} / \mathrm{N}$ ratio in the case of soils form study site $\mathrm{C}$ was even above 30 . The lowest values of $\mathrm{C} / \mathrm{N}$ ratio was observed in the organo-mineral soil profile 2 from site A and organic soil profile 1, site $\mathrm{C}$ (Table 3 ). The obtained results testify the low rate of organic matter mineralization (Lucas 1982). The system of open drainage channels in the SMNP has not been maintained since several years (Kabała et al. 2011). Drainage ditches are partly overgrown by natural vegetation or infilling with sand (Bogacz et al. 2012, Sienkiewicz and Wójcik 2012). It could reduce the water outflow from the investigated peatland areas and increased soil moisture, as defined by Morison (2013).

Recorded concentration of ammonium (range $3.54-24.6 \mathrm{mg} \cdot \mathrm{dm}^{-3}$ ) and nitrate (range $0.03-1.70$ $\mathrm{mg} \cdot \mathrm{dm}^{-3}$ ) forms were very low. The analysis of seasonal nitrogen mineralization $\left(\mathrm{N}-\mathrm{NH}_{4}\right.$ and $\left.\mathrm{N}-\mathrm{NO}_{3}\right)$ showed vast domination of $\mathrm{N}-\mathrm{NH}_{4}$ over the $\mathrm{N}-\mathrm{NO}_{3}$ form in the studied soils (Table 4). The highest mean content of $\mathrm{N}_{-} \mathrm{NO}_{3}$ among study soils were observed in summer and autumn in soils from peatland $\mathrm{C}$ (Table 4). Concentration of $\mathrm{NO}_{3}$ in the study site $\mathrm{C}$ in the summer was significantly higher than in other research transects in this period (Figure 2). Contents of $\mathrm{N}-\mathrm{NO}_{3}$ in soils from study site $\mathrm{A}$ and $\mathrm{B}$ measured during the growing season in 2012 was very low (Table 4, Figure 4). The amount of nitrate nitrogen in investigated soils was strongly positively correlated with air temperature (Table 5). The highest mean content of $\mathrm{N}_{-} \mathrm{NH}_{4}$ in study

TABLE 3. Basic soil properties

\begin{tabular}{|c|c|c|c|c|c|c|c|}
\hline $\begin{array}{c}\text { Study } \\
\text { site }\end{array}$ & $\begin{array}{c}\text { Profile } \\
\text { No. }\end{array}$ & $\begin{array}{l}\text { RF } \\
(\%)\end{array}$ & $\begin{array}{l}\text { Ash } \\
(\%)\end{array}$ & $\begin{array}{l}\mathrm{pH} \text { in } \\
\mathrm{H}_{2} \mathrm{O}\end{array}$ & $\begin{array}{c}\text { TOC } \\
(\%)\end{array}$ & $\begin{array}{l}\mathrm{TN} \\
(\%)\end{array}$ & $\mathrm{C} / \mathrm{N}$ \\
\hline \multirow[t]{8}{*}{$\mathrm{A}$} & 1 & $6-75^{*}$ & $11.2-38.4$ & $4.4-4.6$ & $30.3-40.2$ & $1.46-2.35$ & $16.2-27.4$ \\
\hline & & $35 * *$ & 18.4 & 4.4 & 37.8 & 1.79 & 21.8 \\
\hline & 2 & $5-13$ & $11.0-34.6$ & $3.9-4.5$ & $33.2-40.9$ & $1.79-2.23$ & 14.9-22.9 \\
\hline & & 9 & 21.0 & 4.1 & 38.2 & 2.04 & 19.0 \\
\hline & 3 & $5-9$ & $11.9-59.6$ & $4.3-4.6$ & $16.9-40.2$ & $0.88-1.54$ & $19.2-31.1$ \\
\hline & & 7 & 30.4 & 4.4 & 33.3 & 1.26 & 25.9 \\
\hline & 4 & $5-10$ & $11.2-64.7$ & $3.9-4.4$ & $23.6-40.5$ & $1.01-2.31$ & $14.0-26.9$ \\
\hline & & 7 & 26.7 & 4.2 & 33.7 & 1.77 & 20.1 \\
\hline \multirow[t]{8}{*}{ B } & 1 & $12-39$ & $12.8-25.9$ & $3.9-4.0$ & $39.8-44.1$ & $1.42-1.60$ & $26.7-28.0$ \\
\hline & & 21 & 18.6 & 3.9 & 42.0 & 1.53 & 27.4 \\
\hline & 2 & $14-48$ & $4.31-3.7$ & $3.6-3.9$ & $45.0-49.3$ & $1.15-1.61$ & $29.3-39.1$ \\
\hline & & 38 & 8.80 & 3.8 & 47.5 & 1.44 & 33.3 \\
\hline & 3 & $36-58$ & $4.42-23.8$ & $3.3-3.8$ & $43.2-52.4$ & $1.17-1.97$ & $23.1-40.7$ \\
\hline & & 48 & 11.1 & 3.6 & 47.1 & 1.55 & 32.0 \\
\hline & 4 & $12-54$ & $2.11-25.6$ & $3.4-3.8$ & $44.1-52.5$ & $1.17-2.66$ & $19.7-31.4$ \\
\hline & & 42 & 10.8 & 3.5 & 47.4 & 1.79 & 28.2 \\
\hline \multirow[t]{10}{*}{$\mathrm{C}$} & 1 & $3-39$ & $27.4-82.2$ & $3.4-3.9$ & $14.5-28.4$ & $0.60-1.50$ & $14.2-25.0$ \\
\hline & & 18 & 60.1 & 3.7 & 22.3 & 1.17 & 19.8 \\
\hline & 2 & $35-67$ & $4.62-27.9$ & $3.7-4.2$ & $32.5-43.2$ & $1.04-1.69$ & $\underline{19.3-41.4}$ \\
\hline & & 50 & 11.4 & 3.9 & 41.0 & 1.39 & 30.8 \\
\hline & 3 & $8-85$ & $3.60-43.3$ & $3.8-4.0$ & $29.1-45.0$ & $0.97-1.55$ & 25.4-37.9 \\
\hline & & 43 & 20.1 & 3.9 & 38.4 & 1.33 & 29.3 \\
\hline & 4 & $10-70$ & $7.80-65.9$ & $4.0-4.2$ & $18.1-41.9$ & $0.70-1.39$ & $25.7-42.1$ \\
\hline & & 37 & 25.5 & 4.1 & 35.9 & 1.05 & 34.0 \\
\hline & 5 & $10-45$ & $12.4-63.5$ & $3.5-3.7$ & $17.6-43.6$ & $0.67-1.16$ & $26.5-40.5$ \\
\hline & & 35 & 27.6 & 4.6 & 34.7 & 0.99 & 34.3 \\
\hline
\end{tabular}

Explanation: * range; ** mean; RF - rubbed fiber content; TOC - total organic carbon; TN - total nitrogen. 
TABLE 4. Seasonal dynamic of nitrogen mineralization

\begin{tabular}{|c|c|c|c|c|c|c|c|c|c|c|c|c|c|}
\hline \multirow{3}{*}{$\begin{array}{l}\text { Study } \\
\text { site }\end{array}$} & \multirow{3}{*}{$\begin{array}{l}\text { Soil } \\
\text { profile }\end{array}$} & \multicolumn{4}{|l|}{ Spring } & \multicolumn{4}{|l|}{ Summer } & \multicolumn{4}{|l|}{ Autumn } \\
\hline & & $\mathrm{N}-\mathrm{NO}_{3}$ & $\mathrm{~N}-\mathrm{NH}_{4}$ & SM & water level & $\mathrm{N}-\mathrm{NO}_{3}$ & $\mathrm{~N}-\mathrm{NH}_{4}$ & SM & water level & $\mathrm{N}-\mathrm{NO}_{3}$ & $\mathrm{~N}-\mathrm{NH}_{4}$ & SM & water level \\
\hline & & $\mathrm{mg} \cdot \mathrm{dm}^{-3}$ & & $(\% \mathrm{v} / \mathrm{v})$ & m b.g.l. & $\mathrm{mg} \cdot \mathrm{dm}^{-3}$ & & $(\% \mathrm{v} / \mathrm{v})$ & m b.g.l. & $\mathrm{mg} \cdot \mathrm{dm}^{-3}$ & & $(\% \mathrm{v} / \mathrm{v})$ & m b.g.l. \\
\hline \multirow[t]{8}{*}{$\overline{\mathrm{A}}$} & 1 & $0.03-0.08^{* *}$ & $2.87-17.9$ & $74.1-89.8$ & 0.05 & $0.02-0.09$ & $3.71-11.4$ & $79.1-87.0$ & 0.00 & $0.02-0.13$ & $4.71-25.0$ & $73.1-90.8$ & 0.03 \\
\hline & & $0.05^{* *}$ & 8.41 & 84.2 & & 0.09 & 7.13 & 82.4 & & 0.09 & 10.3 & 81.7 & \\
\hline & 2 & $0.05-1.01$ & $2.33-28.1$ & $84.0-89.9$ & 0.00 & $0.01-0.09$ & $4.08-8.71$ & $76.8-85.9$ & 0.00 & $0.04-0.11$ & $4.40-8.64$ & $78.5-89.0$ & 0.00 \\
\hline & & 0.33 & 10.0 & 81.2 & & 0.04 & 5.65 & 82.8 & & 0.07 & 5.99 & 83.7 & \\
\hline & 3 & $0.02-0.04$ & $2.61-17.0$ & $85.6-91.9$ & 0.02 & $0.02-0.09$ & $2.69-7.93$ & $74.0-81.5$ & 0.10 & $0.03-0.04$ & $4.50-20.1$ & $75.7-82.8$ & 0.05 \\
\hline & & 0.03 & 8.44 & 76.3 & & 0.06 & 5.41 & 77.8 & & 0.04 & 9.58 & 79.3 & \\
\hline & 4 & $0.32-0.44$ & $4.02-24.9$ & $83.7-86.5$ & 0.05 & $0.04-0.08$ & $1.35-12.3$ & $68.6-86.3$ & 0.20 & $0.02-0.06$ & $3.20-20.5$ & $72.1-81.0$ & 0.08 \\
\hline & & 0.36 & 12.7 & 79.1 & & 0.05 & 7.84 & 77.9 & & 0.04 & 8.75 & 76.2 & \\
\hline \multirow[t]{8}{*}{$\bar{B}$} & 1 & $0.02-0.13$ & $6.45-16.9$ & $77.2-81.6$ & 0.10 & $0.03-0.07$ & $7.75-18.0$ & $76.6-80.4$ & 0.08 & $0.02-0.04$ & $3.95-7.13$ & $76.0-81.3$ & 0.10 \\
\hline & & 0.06 & 12.2 & 79.7 & & 0.06 & 11.4 & 78.9 & & 0.03 & 5.49 & 79.5 & \\
\hline & $\overline{2}$ & $0.03-0.19$ & $8.44-27.7$ & $82.2-92.6$ & 0.05 & $0.05-0.42$ & $6.38-10.0$ & $82.7-87.0$ & 0.05 & $0.03-0.06$ & $3.72-11.4$ & $83.6-90.7$ & 0.05 \\
\hline & & 0.09 & 18.5 & 86.8 & & 0.18 & 7.62 & 85.5 & & 0.04 & 7.87 & 87.0 & \\
\hline & 3 & $0.03-0.61$ & $2.16-21.4$ & $62.0-92.2$ & 0.15 & $0.03-0.62$ & $2.27-29.3$ & $86.0-90.8$ & 0.05 & $0.03-0.05$ & $4.59-21.2$ & $75.2-91.0$ & 0.15 \\
\hline & & 0.22 & 11.8 & 88.2 & & 0.23 & 13.5 & 88.9 & & 0.04 & 10.1 & 86.0 & \\
\hline & 4 & $0.02-0.16$ & $5.56-20.4$ & $89.5-92.0$ & 0.10 & $0.02-0.09$ & $1.54-23.2$ & $80.7-85.3$ & 0.10 & $0.04-0.08$ & $5.10-13.2$ & $83.5-88.3$ & 0.12 \\
\hline & & 0.05 & 11.3 & 85.3 & & 0.04 & 9.56 & 83.4 & & 0.06 & 9.60 & 86.3 & \\
\hline \multirow[t]{10}{*}{$\overline{\mathrm{C}}$} & 1 & $0.07-0.54$ & $2.92-9.42$ & $64.6-87.2$ & 0.20 & $0.48-1.12$ & $0.72-9.26$ & $38.1-54.5$ & 0.40 & $0.21-0.73$ & $2.63-9.61$ & $65.3-70.8$ & 0.22 \\
\hline & & 0.30 & 4.99 & 73.4 & & 0.68 & 3.54 & 48.0 & & 0.38 & 5.15 & 70.6 & \\
\hline & 2 & $0.04-0.05$ & $7.36-23.3$ & $82.2-92.6$ & 0.10 & $0.59-0.95$ & $5.69-27.8$ & $83.5-90.7$ & 0.15 & $0.42-0.68$ & $6.38-20.5$ & $84.0-9.18$ & 0.13 \\
\hline & & 0.04 & 14.7 & 89.0 & & 0.83 & 14.1 & 86.3 & & 0.54 & 13.6 & 89.1 & \\
\hline & 3 & $0.02-0.28$ & $3.32-9.23$ & $62.0-92.2$ & 0.14 & $0.79-1.56$ & $1.79-15.0$ & $54.7-81.7$ & 0.20 & $0.17-0.52$ & $6.38-8.74$ & $66.4-71.8$ & 0.17 \\
\hline & & 0.09 & 5.13 & 80.6 & & 1.02 & 5.26 & 70.1 & & 0.36 & 7.44 & 74.7 & \\
\hline & 4 & $0.10-1.01$ & $7.85-24.1$ & $89-91.8$ & 0.10 & $0.58-3.00$ & $14.7-30.0$ & $88.8-90.9$ & 0.07 & $0.35-1.05$ & $18.0-29.4$ & $73.0-92.9$ & 0.10 \\
\hline & & 0.37 & 16.4 & 91.2 & & 1.21 & 22.5 & 90 & & 0.55 & 24.6 & 84.8 & \\
\hline & 5 & $0.17-0.67$ & $5.27-15.7$ & $48.1-93.0$ & 0.27 & $0.68-2.49$ & $2.63-19.7$ & $69.6-90.1$ & 0.40 & $0.12-0.48$ & $1.04-19.2$ & $51.0-83.7$ & 0.36 \\
\hline & & 0.37 & 12.4 & 77.9 & & 1.70 & 10.6 & 79.6 & & 0.33 & 8.10 & 71.6 & \\
\hline
\end{tabular}

Explanation: *range, ${ }^{* *}$ mean value; SM - soil moisture; b.g.l. - below ground level. 


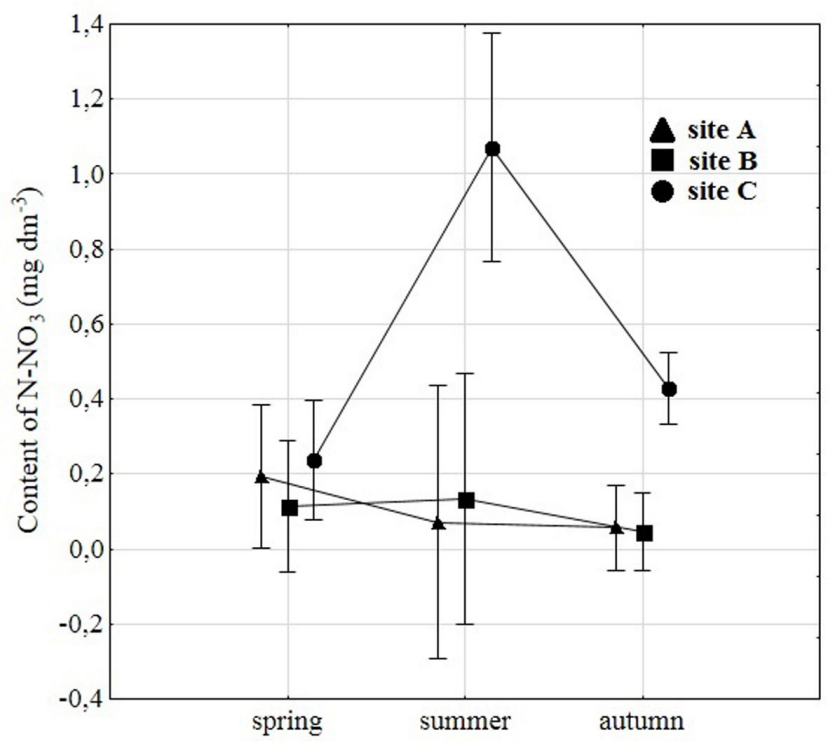

FIGURE 2. Comparison of seasonal variability of $\mathrm{N}-\mathrm{NO}_{3}$ content (mean values) between study sites

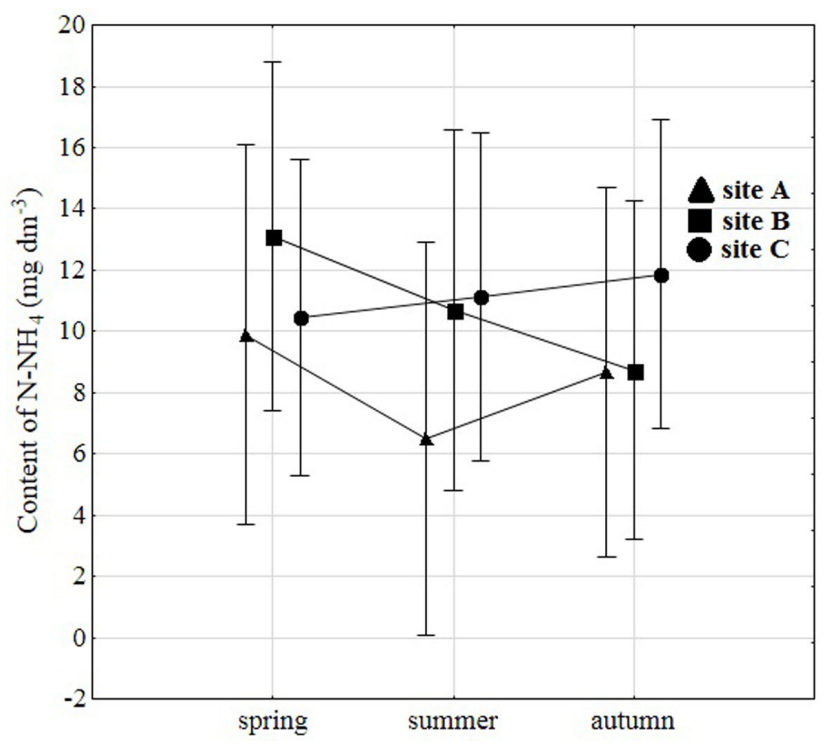

FIGURE 3. Comparison of seasonal variability of N-NH $\mathrm{N}_{4}$ content (mean values) between study sites

soil profiles during the growing season 2012 was observed in peatland C (Figure 5). However, statistically significant seasonal differentiation among the study sites was not observed (Figure 3). The amount of ammonium nitrogen in investigated soils was

TABLE 5. Pearson correlation coefficient between mineral nitrogen forms and selected environmental factors $(\mathrm{n}=117)$

\begin{tabular}{lllll}
\hline & $\begin{array}{l}\text { Soil } \\
\text { Moisture }\end{array}$ & Temperature & Precipitation & $\begin{array}{l}\text { Groundwater } \\
\text { level }\end{array}$ \\
\hline $\mathrm{N}-\mathrm{NO}_{3}$ & -0.155 & $0.356^{*}$ & 0.253 & -0.184 \\
\hline $\mathrm{N}-\mathrm{NH}_{4}$ & $0.570^{*}$ & -0.139 & -0.142 & $0.544^{*}$ \\
\hline
\end{tabular}

*correlation significant at $\mathrm{p}<0.05$.

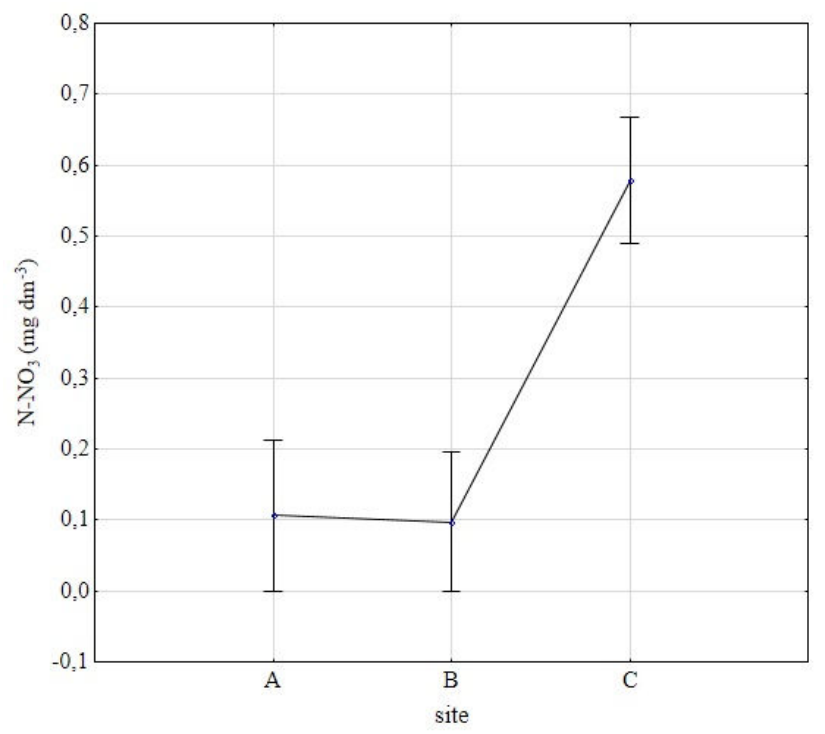

FIGURE 4. Mean content of $\mathrm{N}-\mathrm{NO}_{3}$ in each study site during the growing season 2012

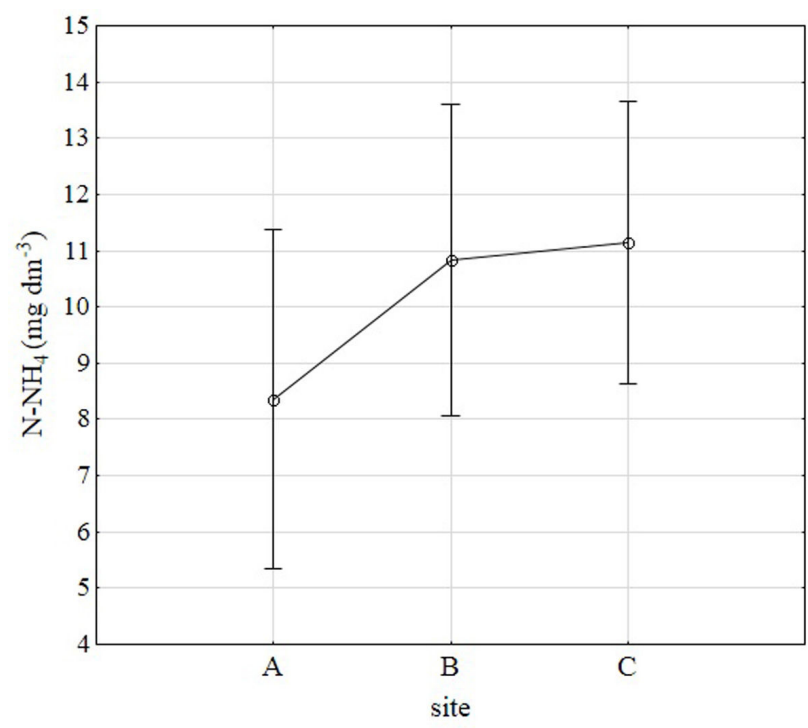

FIGURE 5. Mean content of $\mathrm{N}^{-\mathrm{NH}_{4}}$ in each study site during the growing season 2012

strongly positively correlated with actual soil moisture $(\mathrm{r}=0.570)$ and groundwater level $(\mathrm{r}=0.544)$ (Table 5).

Based on results described above, it can be stated that investigated organic soils are under weak mineralization process, what is confirmed by dominance of ammonium $\mathrm{N}-\mathrm{NH}_{4}$ over the nitrate $\mathrm{N}^{-\mathrm{NO}_{3} \text { forms }}$ (Bayley et al. 2005, Gao et al. 2009). This might be the effect of high groundwater level appearing periodically in the year. The high soil moisture limits the microbial activity (Makarov et al. 2010), responsible for nitrogen mineralization (Lapalainen et al. 2013). On the other hand, the domination of ammonium over the nitrate form in the mountain peatlands, particularly in the surface soil layers often is the effect of atmospheric deposition (Evans et al. 2000). Higher $\mathrm{N}^{-\mathrm{NO}_{3}}$ 
concentrations in soils along the research transect $\mathrm{C}$ than in the transects A and B, might be the effect of water discharged by drainage ditches. Długie Mokradło bog (site C) is the most densely cut by network of drainage ditches (spacing from 1 to 3 meters) among all of the investigated peatlands (Glina 2014). Moreover in the peatlands A and B the vast portion of ditches are overgrown by natural succession or filled with sand (Kabała et al. 2011, Bogacz et al. 2012, Glina 2014), what limits the water outflow (Parry et al. 2014). Furthermore, higher temperatures might stimulate microbial activity (Gao et al. 2009) and evapotranspiration (Morison 2013), thereby accelerate the nitrogen mineralization process (Keller et al. 2004, Jonczak 2013). Observed significant dependency between ammonium nitrogen concentrations in mountain peatland soils and actual soil moisture are in line with findings reported by Keller et al. (2004) and Bayley et al. (2005). Mentioned authors described significant positive correlations between soil moisture and $\mathrm{N}-\mathrm{NH}_{4}$ concentration in boreal peat bogs. In ombrotrophic peatlands, soil moisture is exclusively determined by precipitation rate, which plays an important role in controlling the $\mathrm{N}$ mineralization in the organic soils (Charman et al. 2008).

\section{CONCLUSIONS}

1. The weak nitrogen mineralization in the investigated soils is the result of limiting water outflow from peatland areas by infilling drainage ditches with mineral material and overgrowing by natural succession.

2. The highest concentration of nitrate nitrogen form was observed in the organic soils from Dlugie Mokradło bog (study site C), what is the effect of water discharged by dens net of drainage ditches.

3. The content of ammonium nitrogen $\left(\mathrm{N}-\mathrm{NH}_{4}\right)$ was mainly determined by actual soil moisture and precipitation rate, whereas the content of nitrate form $\left(\mathrm{N}-\mathrm{NO}_{3}\right)$ by air temperature and drainage.

4. The clear criteria for shallow organic soils classification and implementation of shallow fibric peat soils subtype (in Polish: gleby torfowe fibrowe płytkie) within the type of peat soils should be considered during developing of the next update of Polish Soil Classification.

\section{ACKNOWLEDGMENTS}

The research was co-financed by the European Union as part of the European Social Fund - „Grant Plus" program, Grant No. DG-G, 4170/13. Special thanks to Łukasz Mendyk for his help in preparation of location figure.

\section{REFERENCES}

Basiliko N., Moore T.R., Lafleur P.M., Roulet N.T., 2005. Seasonal and inter-annual decomposition, microbial biomass, and nitrogen dynamics in a Canadian bog. Soil Science 170: 902-912.

Bayley S.E., Thormann M.N., 2005. Nitrogen mineralization in western boreal bog and fen peat. Ecoscience 12(4): 455-465.

Bojko O., Kabała C., 2014. Loss-on-ignition as an estimate of total organic carbon in the mountain soils. Polish Journal of Soil Science 47(2): 71-79.

Bogacz A., 2005. Właściwości i stan przeobrażenia wybranych gleb organicznych Sudetów. Zeszyty AR we Wrocławiu. Rozprawy 507: 1-147.

Bogacz A., Ochej A., Niemirowska I., 2008. Organic soil properties in selected areas in Bialskie Mountains. Roczniki Gleboznawcze - Soil Science Annual 59(3/4): 31-40.

Bogacz A., Roszkowicz M., 2010. Influence of forest management on the changes of organic soil properties in marginal part of Kragle Mokradło Peatlands (Stołowe Mountains National Park). Roczniki Gleboznawcze - Soil Science Annual 61(2): 15-20.

Bogacz A., Rutkowska H., 2010. Organic soils in the valley areas of the Stołowe Mountians National Park. Roczniki Gleboznawcze - Soil Science Annual 61(4): 15-25.

Bogacz A., Dzięcioł D., Glina B., Gersztyn L., 2012. Peat soils in the restoration Niknaca Laka peatland in the Stołowe Mountains National Park. Roczniki Gleboznawcze - Soil Science Annual 63(2): 3-8.

Charman D., Laine J., Minayeva T., Sirin A., 2008. Impacts on future climate change on peatlands. [In:] Assessment on Peatlands, Biodiversity and Climate Change: Main Report (Parish F., Sirin A., Charman D., Joosten H., Minayeva T., Silvius M. and Stringer L., Editors). A Global Environment Centre, Kuala Lumpur and Wetlands International, Wageningen: 139-154.

Ehrenfeld J.G., Shen Yu., 2012. Patterns of Nitrogen Mineralization in Wetlands of the New Jersey pinelands along a Shallow Water Table Gradient. The American Midland Naturalist 167(2): 322-335.

Evans C.D., Jenkins A., Wright R.F., 2000. Surface water acidification in the South Pennines - Current status and spatial variability. Environmental Pollution 109: 11-20.

Ferrati R., Canziani G.A., Moreno D.R., 2005. Estero del Ibera: hydrometeorological and hydrological characterization. Ecological Modelling 186: 3-15.

Gałka B., Łabaz B., Bogacz A., Bojko O., Kabała C., 2014. Conversion of Norway spruce forests will reduce organic carbon pools in the mountains soils of SW Poland. Geoderma 213: 287-295.

Gao J.Q., Ouyang H., Xu X.L., Zhou C.P., Zhang F., 2009. Effects of temperature and water saturation on $\mathrm{CO}_{2}$ production and nitrogen mineralization in alpine wetland soils. Pedosphere 19: 71-77.

Gillooly J.F., Brown J.H., West G.B., Savage V.M., Charnov E.L., 2001. The universal metabolic rate: effects of size and temperature on the metabolic rate of plants, animals, and microbes. Science 293: 2248-2251.

Glina B., Bogacz A., 2013. Concentrations and pools of trace elements in organic soils in the Izera Mountains. Journal of Elementology 18(2): 199-209. 
Glina B., Bogacz A., Kordyjarek M., Bojko O., 2013. Diversity of soils in the peatland located on slope near Karłów (SMNP). Episteme 18(3): 287-296.

Glina B., 2014. Spatial variability of the shallow organic soils in the Stołowe Mountains as a results of anthropogenic transformations. PhD thesis, Wrocław: 208 pp.

Gotkiewicz J., 1974. Zastosowanie metody inkubowania próbek o nienaruszonej strukturze do badań nad mineralizacją azotu w glebach torfowych. Roczniki Nauk Rolniczych, Seria F 78(4): 25-34.

IUSS Working Group WRB, 2015. World reference base for soil resources 2014, update 2015. International Soil Classification System for Naming Soil and Creating Legends for Soil Maps. Food and Agriculture Organization of the United Nations, Rome: $190 \mathrm{pp}$.

Jędryszczak E., Miścicki S., 2001. Forests of the Stołowe Mountains National Park. Szczeliniec 5: 79-103.

Jonczak J., 2013. Effect of peat samples drying on measured content of carbon and nitrogen fractions. Roczniki Gleboznawcze Soil Science Annual 64(4): 130-134.

Kabała C., Chodak T., Bogacz A., Łabaz B., Jezierski P., Gałka B., Kaszubkiewicz J., Glina B., 2011. Spatial variability of soils and habitats in the Stołowe Mountains. [In:] Geo-ecological Conditions of the Stołowe Mountains National Park (Chodak T., Kabała C., Editors). Wind, Wrocław, Poland: 141167.

Kabała C. (ed.)., 2015. Soils of Lower Silesia: origins, diversity, and protection. PTG, PTSH. Wrocław: $256 \mathrm{pp}$.

Keller J.K., White J.R., Bridgham S.D., Pastors J., 2004. Climate changes effect on carbon and nitrogen mineralization in peatlands through changes in soil quality. Global Change Biology 10: 1053-1064.

Lapalainen M., Kukkonen J.U.K., Pirainen S., Sarjala T., 1999. Nitrogen release in decomposition of boreal mor and peat as affected by enchytraeid worms. Boreal Environment Reaserch 18: 181-194.

Limpens J., Berendse F., Blodau C., Canadell J.G., Freeman C., Holden J., Roulet N., Rydin H., Schapeman-Strub G., 2008. Peatlands and the carbon cycle: from local processes to global implications-a synthesis. Biogeosciences 5: 1379-1419.

Lucas R.E., 1982. Organic soils (Histosols). Formation, distribution, physical and chemical properties and management for crop production. Farm Science Review 452: 3-77.

Lynn W.C., McKinzie W.E., Grossmann R.B., 1974. Field laboratory test for characterization of Histosols. [In:] Histosols: Their Characteristic and Use (Stelly M., Editor). SSSA Spec. Pub, 6 Medison: 11-20.
Łajczak A., 2013. Role of land relief and structure in the formation of peat bogs in mountain areas, as exemplified by the Polish Carpathians. Landform Analysis 22: 61-73.

Makarov M.I., Leoshkina N.A., Ermak A.A., Malysheva T.I., 2010. Seasonal Dynamic of the Mineral Nitrogen Forms in Mountain-Meadow Alpine Soil. Eurasian Soil Science 43(8): 905-913.

Maljanen M., Hytonen J., Makiranta P., Alm J., Minkkinen K., Laine J., Martikainen P.J., 2007. Greenhouse gas emissions from cultivated and abandoned organic croplands in Finland. Boreal Environment Research 12: 133-140.

Markiewicz M., Mendyk Ł., Gonet S.S., 2015. Soil organic matter status in agricultural soil sequence of former shoreline of disappearing Sumowskie lakes, North-Eastern Poland. Polish Journal of Soil Science 48(1): 65-78.

Morison J.I.L., 2013. Afforested peatland restoration. Forest Research - Climate Change: 13 pp.

Parry L.E., Holden J., Chapman P.J., 2014. Restoration of blanket peatlands. Journal of Environmental Management 133: 193-205.

Pawluczuk J., Szymczyk S., 2008. Dynamics of mineral nitrogen mineralization in muck soils of dymerskie meadows and the content of nitrate and ammonium nitrogen in groundwater. Woda-Środowisko-Obszary Wiejskie 24(2): 105-115.

Polish Soil Classification (Systematyka gleb Polski), 2011. Roczniki Gleboznawcze - Soil Science Annual 62(3): 1-193.

Schimel J.P., Bennett J., 2004. Nitrogen mineralization: challenges of a changing paradigm. Ecology 85: 591-602.

Sienkiewicz J., Wójcik G., 2012. Plan ochrony Parku Narodowego Gór Stołowych - operat ochrony ekosystemów torfowiskowych. Warszawa: $24 \mathrm{pp}$.

Stark L., 1936. Zur Geschlichte der Moor und Walder Schliesens in postglazialer Zeit. Botanische Jahrbucher 67: 494-640.

Tripathi N., Sighn R.J., 2009. Influence on different land uses on soil nitrogen transformations after conversion from an India dry tropical forest. Catena 77: 216-233.

Turbiak J., Miatkowski Z., 2006. Zawartość azotu azotanowego w głęboko odwodnionych glebach torfowo-murszowych. Zeszyty Problemowe Postępów Nauk Rolniczych 513: 507-516.

Weedon J.T., Kowalchuk G.A., Aerts R., van Hal J., van Logtestijn R., Tas N., Röling W.F.M., van Bodegom P.M., 2012. Summer warming accelerates sub-arctic peatland nitrogen cycling without changing enzyme pools or microbial community structure. Global Change Biology 18: 138-150.

Yallop A.R., Clutterbuck B., 2009. Land management as a factor controlling dissolved organic carbon release from upland peat soils 1: spatial variation in DOC productivity. Science of the Total Environment 407: 3803-3813.

Received: March 8, 2016

Accepted: July 14, 2016 


\title{
Mineralizacja organicznych związków azotu w odwodnionych glebach z obszaru torfowisk użytkowanych leśnie w Parku Narodowym Gór Stołowych (Sudety Środkowe)
}

\begin{abstract}
Streszczenie: Celem niniejszej pracy była ocena intensywności mineralizacji organicznych związków azotu w glebach torfowiskowych w Parku Narodowym Gór Stołowych zdrenowanych pod użytkowanie leśne. Dodatkowo w pracy poddano dyskusji problem klasyfikacji płytkich gleb organicznych według kryteriów zawartych w aktualnie obowiązującej Systematyce Gleb Polski (2011). W ramach badań zaprojektowano trzy transekty badawcze na obszarze torfowisk ombrogenicznych porośniętych głównie drzewostanem świerkowym. Każdy z transektów składał się z czterech (obiekt A i B) lub pięciu (obiekt C) powierzchni badawczych. Próbki gleby do podstawowych analiz właściwości gleb pobrano w kwietniu z każdego poziomu genetycznego. Natomiast próbki gleby o nienaruszonej strukturze do analizy sezonowej dynamiki mineralizacji azotu pobrano w kwietniu (wiosna), lipcu (lato) i październiku (jesień) roku 2012 z warstw 0-10 cm, 10-20 cm, 20-30 cm itd. Liczba próbek była warunkowana miąższością profilu glebowego. Analiza statystyczna wykazała, że zawartość $\mathrm{N}-\mathrm{NH}_{4}$ w badanych glebach było determinowane głównie przez aktualną wilgotność gleby oraz wielkość opadów. Zawartości $\mathrm{N}_{-} \mathrm{NO}_{3}$ wykazywała tendencję wzrostową w okresach z wyższą temperaturą powietrza. Spośród badanych torfowisk najwyższe zawartości mineralnych form azotu zaobserwowano w glebach organicznych z obszaru Długiego Mokradła (obiekt C), położonego na wierzchowinie Skalniaka. Dodatkowo, przedstawiona praca wykazała potrzebę dodania nowego podtypu gleb torfowych fibrowych płytkich w obrębie typu gleb torfowych, co powinno być wzięte pod uwagę podczas opracowywania kolejnej aktualizacji Systematyki Gleb Polski.
\end{abstract}

Słowa kluczowe: azot mineralny, użytkowanie leśne, drenaż, torfowiska wysokie, Sudety 